\title{
PENENTUAN KADAR LOGAM TIMBAL PADA RAMBUT SUPIR BUS RUTE TANGERANG-PADANG-SURABAYA-YOGYAKARATA DI TERMINAL PORIS TANGERANG
}

\section{DETERMINATION OF LEAD METAL LEVELS IN HAIR DRIVER BUS ROUTE TANGERANG-PADANG-SURABAYA AT PORIS BUS STATION TANGERANG}

\author{
Nurmeily Rachmawati ${ }^{1}$, Syarah Anliza ${ }^{2}$, Hayyana Hilya ${ }^{3}$, Setiani Indah Lestari ${ }^{4}$, Novita ${ }^{5}$ \\ 1,2,3,4,5 Poltekkes Kemenkes Banten \\ (email penulis korespondensi:nurmeily.rachmawati@gmail.com)
}

Info Artikel: Diterima: 20 Oktober 2020 Revisi: 25 November 2020 Disetujui: 15 Desember 2020

\begin{abstract}
ABSTRAK
Latar Belakang : Pencemaran di udara salah satunya dapat disebabkan oleh emisi buangan gas kendaraan yang dapat melepaskan zat timbal ke udara. Salah satu orang yang dapat beresiko terpapar logam timbal adalah pekerja supir bus. Pajanan logam timbal dapat terakumulasi di dalam rambut dan dapat menyebabkan efek toksisitas. Tujuan penelitan untuk mengetahui kadar logam timbal $(\mathrm{Pb})$ pada rambut supir bus di tiga rute berbeda yang berangkat dari Terminal Poris, Tangerang. Ketiga rute tersebut adalah Tangerang-Padang, Tangerang-Surabaya, Tangerang-Yogyakarta.

Metode : Penelitian ini merupakan jenis experimental dengan jumlah korespondensi setiap rute bis masing-masing sebanyak 8 orang. Penentuan kadar logam timbal pada rambut supir bus menggunakan spektrofotometer ICP-OES.

Hasil : Penelitian ini memberikan hasil bahwa semua sampel rambut supir bus diketiga rute teridentifikasi logam timbal. Kadar logam timbal terbesar pada rambut supir bus rute TangerangPadang yaitu 2,28 mg Pb/100 g dengan masa kerja 25 tahun. Sedangkan kadar logam timbal terendah pada rambut supir bus rute Tangerang-Surabaya yaitu $0,17 \mathrm{mg} \mathrm{Pb} / 100 \mathrm{~g}$ dengan masa kerja 3 tahun. Berdasarkan uji statistic analisis korelasi diperoleh nilai $r=0,82$. Nilai $r$ yang mendekati 1 ini menunjukkan korelasi positif antara masa lama bekerja supir bis dengan kadar paparan logam timbal yang terdeteksi.
\end{abstract}

Kesimpulan : Seluruh supir bus diketiga rute teridentifikasi logam timbal dengan konsentrasi yang berbeda-beda dengan masa kerja yang bervariasi.

Kata kunci : Logam timbal, rambut supir bis, spektrofotometer

\begin{abstract}
Background: One of the causes of air pollution is vehicle exhaust emissions which can release lead metal into the air. One of the people who can be at risk to the exposure of lead metal is bus driver workers. Lead metal exposure can accumulate in the hair and can cause toxicity effects. The objective of this research is to determine the level of lead $(P b)$ in the hair of bus drivers on three different routes departing from Terminal Poris, Tangerang. The three routes are Tangerang-Padang, Tangerang-Surabaya, Tangerang-Yogyakarta.

Methods : The method used in this research is experimental research with 8 correspondences for each of bus route. Determination of the level of lead metal in the bus driver's hair is using an ICPOES spectrophotometer.

Results : The results showed that all the hair samples of the bus drivers in the three routes were contaminated as lead metal. The largest concentration of lead metal in the hair of bus drivers on the Tangerang-Padang route is $2.28 \mathrm{mg} \mathrm{Pb} / 100 \mathrm{~g}$ with 25 years of working periods. Meanwhile, the lowest level of lead in the hair of bus drivers on the Tangerang-Surabaya route is $0.17 \mathrm{mg} \mathrm{Pb} / 100 \mathrm{~g}$ with 3 years working periods. Based on statistics result corelation analysis showed value $r=0,82$. These value approximately one indicate positif corellation between working periods and level of lead metal that detected in driver bus body.
\end{abstract}

Conclusion : The samples hair of the three bus drivers was contaminated with lead metal with different concentrations in various working periods

Keywords : Lead metal, bus driver's hair, spectrophotometer 


\section{PENDAHULUAN}

Indonesia merupakan negara dengan tingkat pencemaran udara yang cukup tinggi dengan menempati posisi ke-3 didunia. ${ }^{1}$ Pencemaran udara dapat berasal dari industri, asap pembakaran bahan bakar kendaraan, pembakaran, dll. Transportasi menghasilkan emisi yang dapat menyumbang tingkat pencemaran udara hingga sekitar $85 \%{ }^{2}$ Menurut data Dinas Lingkungan Hidup, 2019 penyumbang polusi udara diantaranya berasal dari $75 \%$ transportasi darat dan sisanya berasal dari industri, pembangkit listrik, dan pembakaran domsetik. Pada transportasi darat ini didiproduksi oleh asap kendaraan yang mengandung logam timbal. Paparan logam timbal di udara sangat berbahaya bagi orang yang memiliki pekerjaan yang selalu berkaitan dengan zat tersebut walaupun pada kadar rendah. Logam timbal yang terhirup dapat diabsorpsi oleh paru - paru sekitar 2-3 kali lebih besar dibandingkan yang tertelan/diabsorpsi melalui saluran cerna, sedangkan $30-40 \%$ akan diabsorpsi oleh saluran pernafasan akan masuk ke aliran darah. Kemudian akan di distribusikan ke dalam jaringan lunak seperti sel hati dan akan terakumulasi di dalam rambut, tulang, dan gigi untuk dideposit. ${ }^{3}$

Timbal $(\mathrm{Pb})$ merupakan logam berat dan termasuk kedalam jenis logam transisi golongan B yang bersifat toksik. Logam ini dapat ditemukan pada hasil emisi kendaraan yang dapat terabsorpsi kedalam tubuh manusia melalui udara. ${ }^{4}$ Emisi kendaraan yang mengandung logam timbal ini dapat ditemukan diterminal bis maupun jalanan kendaraan. Pada tempat-tempat tersebut banyak kendaraan seperti bus, angkutan perkotaan, dan kendaraan

\section{METODE}

Penelitian ini merupakan jenis penelitian ekperimental dimana lokasi sampling dilakukan di Terminal Poris, Tangerang. Populasi pada penelitian ini adalah seluruh supir bus yang bekerja di Terminal Poris dengan sampel penelitian rambut supir bus dengan rute Tangerang-Padang, Tangerang-Surabaya, Tangerang-Yogyakarta yang totalnya berjumlah 24 sampel rambut supir bus diketiga rute tersebut. Penelitian ini dilakukan pada bulan Januari-Mei 2020. Teknik purposive sampling digunakan dengan kriteria supir bus yang bekerja minimal 3 tahun dengan rute bis lainnya yang menggunakan bahan bakar bensin. Hal ini menyebabkan udara menjadi tercemar akibat gas hasil pembakaran bahan bakar tersebut. Selain emisi kendaraan, pencemaran udara juga dapat bertambah akibat aktivitas manusia seperti merokok. ${ }^{5}$ Menurut Environment Project Agency (EPA), asap knalpot dari kendaraan menyumbang $3 / 4$ polusi udara dan sisanya tetap berada dalam kendaraan mesin tersebut. Emisi $\mathrm{Pb}$ dari gas buangan kendaraan tersebutlah yang dapat membahayakan kesehatan manusia bagi yang tidak sengaja menghirupnya. ${ }^{6}$

Penelitian yang dilakukan oleh Mukhtar (2013) didapatkan hasil konsentrasi logam timbal dalam udara di Kota Tangerang sebesar $2045 \mathrm{ng} / \mathrm{Nm}^{3}$. Nilai ini melebihi baku mutu udara ambien menurut PP No.41/1999 yaitu baku mutu $\mathrm{Pb}$ dalam total suspended particulate (TSP) adalah $2000 \mathrm{ng} / \mathrm{Nm}^{3}{ }^{3}$. Pada Kota Surabaya menempati posisi tertinggi yaitu 2,6 $\mu \mathrm{g} / \mathrm{Nm}^{3}$ dan untuk Kota Padang berdasarkan penelitian Ruslinda (2016) konsentrasi $\mathrm{Pb}$ di udara Jalan Raya Kota Padang sebesar 1,060$1,504 \mathrm{ng} / \mathrm{Nm}^{3} .{ }^{8}$ Sedangkan pada Kota Yogyakarta berdasarkan penelitian Abidin pada tahun 2009 konsentrasi $\mathrm{Pb}$ didapatkan hasil sebesar $0,963-1,805 \mathrm{ng} / \mathrm{Nm}^{3}{ }^{3}$. Tingginya pencemaran udara dikota-kota tersebut dapat mengindikasi paparan yang terpajan pada supir bus dengan rute diketiga kota tersebut. Masa bekerja supir juga dapat mempengaruhi kadar logam timbal yang terpapar. Berdasarkan hal tersebut perlu dilakukan identifikasi kadar logam timbal terhadap supir bus yang bekerja pada rute bis Tangerang-Padang, TangerangSurabaya, dan Tangerang-Yogyakarta.

Tangerang-Surabaya, Tangerang-Padang, dan Tangerang-Yogyakarta.

Pengambilan data penelitian dilakukan dengan melakukan survei kepada supir bus yang memenuhi kriteria penelitian, pengambilan sampel rambut \pm 1 gram, dan analisa kadar timbal dilakukan di Laboratorium Kesehatan Daerah Provinsi DKI Jakarta menggunakan spektrofotometer ICP-OES. Data penelitian ini kemudian disajikan dalam bentuk tabel serta dianalisis secara deskriptif serta uji statistik analisis korelasi antara masa bekerja dengan kadar paparan logam timbal. 


\section{HASIL}

Penelitian dilakukan dengan melakukan survey terlebih dahulu kepada supir bus yang berada di Terminal Poris, Tangerang dengan syarat kriteria yang memenuhi. Survey terdiri dari nama, usia, jenis kelamin, lama bekerja, dan kebiasan merokok. Berdasarkan hasil survey tersebut diperoleh sampel penelitian sebanyak 8 orang untuk setiap rute bis. Total sampel menjadi 24 sampel yang akan dianalisa kandungan logam timbal di rambut supir bis tersebut. Rambut supir bis diambil \pm 1 gram dari ujung pangkal rambut yang kemudian diberi label untuk masing-masing sampel dan dianalisa menggunakan spektrofotometer ICPOES pada panjang gelombang 220,35 nm. Sebelum dilakukan analisa kadar logam timbal dirambut supir bis, maka terlebih dahulu dilakukan pembuatan kurva kalibrasi dari larutan standar dari konsentrasi $0.025 \mathrm{ppm}$ sampai 0.5 ppm sesuai dengan kurva dibawah ini. Hasil pembacaan larutan standar ini kemudian diolah untuk dijadikan kurva kalibrasi seperti pada Gambar 1 sebagai berikut:

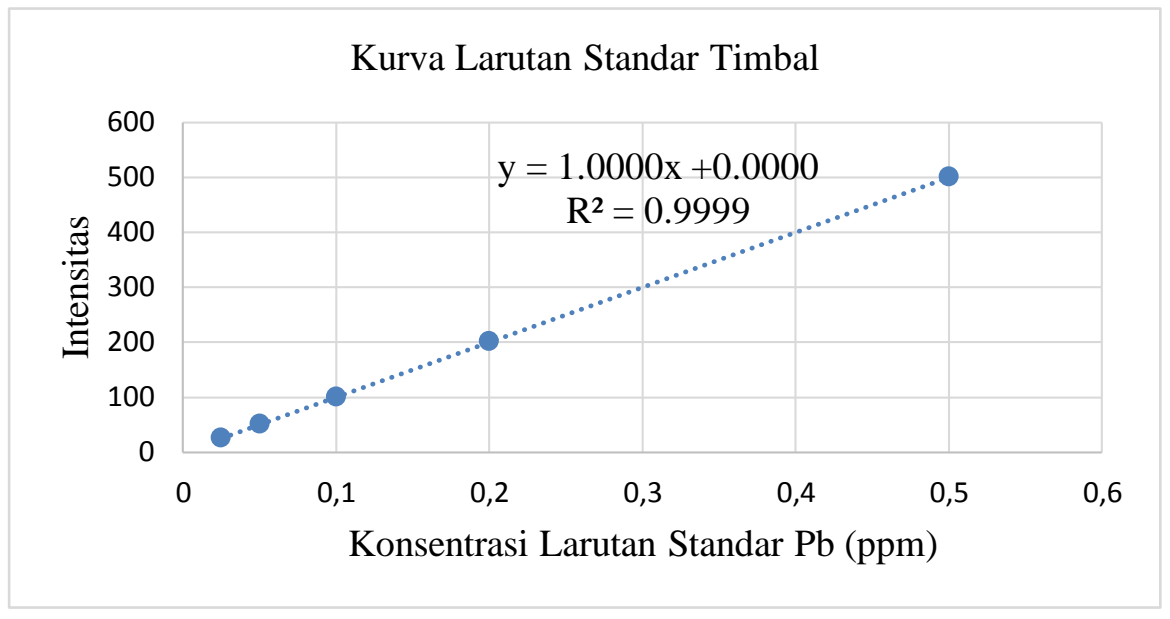

Gambar 1. Kurva Kalibrasi Larutan Standar Timbal

Hasil pembacaan larutan standar dari spektrofotometer kemudian diolah dalam gambar 1. kurva kalibrasi ini menyatakan bahwa metode ini memiliki linearitas yang baik dan telah sesuai standar metode US.EPA 200.7 sehingga dapat dikatakan bahwa metode ynag digunakan dalam penelitian ini merupakan metode yang baik dan dapat memberikan hasil yang valid. Selanjutnya dilakukan pengujian sampel dengan mengacu pada metode analisa Ruxin Luo, $2017^{10}$ dimana sampel akan digesti dengan asam nitrat dan hidrogen peroksida dan kemudian diencerkan dengan akuadest hingga batas tera pada labu ukur. Berikut adalah hasil pemeriksaan kadar logam timbal di sampel tersebut. 
Tabel 1. Hasil Pemeriksaan Kadar Logam Timbal pada Rambut Supir Bus diketiga Rute di Terminal Poris, Tangerang

\begin{tabular}{|c|c|c|c|}
\hline No. & Kode Sampel & $\begin{array}{c}\text { Masa Kerja } \\
\text { (Tahun) }\end{array}$ & $\begin{array}{c}\text { Kadar Pb } \\
(\mathrm{mg} \mathrm{Pb} / 100 \text { g) }\end{array}$ \\
\hline \multicolumn{4}{|c|}{ Rute Tangerang-Padang } \\
\hline 1. & TP1 & 25 tahun & 2,28 \\
\hline 2. & TP2 & 10 tahun & 0,61 \\
\hline 3. & TP3 & 7 tahun & 0,41 \\
\hline 4. & TP4 & 5 tahun & 0,33 \\
\hline 5. & TP5 & 20 tahun & 2,21 \\
\hline 6. & TP6 & 15 tahun & 0,64 \\
\hline 7. & TP7 & 12 tahun & 0,61 \\
\hline 8. & TP8 & 18 tahun & 1,11 \\
\hline \multicolumn{4}{|c|}{ Rute Tangerang-Surabaya } \\
\hline 1. & TS1 & 6 tahun & 0.54 \\
\hline 2. & TS2 & 3 tahun & 0,25 \\
\hline 3. & TS3 & 5 tahun & 0,54 \\
\hline 4. & TS4 & 5 tahun & 0,35 \\
\hline 5. & TS5 & 7 tahun & 1,20 \\
\hline 6. & TS6 & 5 tahun & 0,33 \\
\hline 7. & TS7 & 3 tahun & 0,17 \\
\hline 8. & TS8 & 11 tahun & 1,91 \\
\hline \multicolumn{4}{|c|}{ Rute Tangerang-Yogyakarta } \\
\hline 1. & TY1 & 8 tahun & 0,56 \\
\hline 2. & TY2 & 15 tahun & 0,73 \\
\hline 3. & TY3 & 17 tahun & 1,17 \\
\hline 4. & TY4 & 3 tahun & 0,37 \\
\hline 5. & TY5 & 10 tahun & 0,57 \\
\hline 6. & TY6 & 3 tahun & 0,35 \\
\hline 7. & TY7 & 22 tahun & 1,81 \\
\hline 8. & TY8 & 11 tahun & 0,68 \\
\hline
\end{tabular}

Selanjutnya dilakukan analisis data dengan membandingkan pada ambang batas yaitu 0,007-1,17 $\mathrm{mg} / 100 \mathrm{~g} \mathrm{~Pb}{ }^{19}$ dan uji statistic analisis korelasi antara masa bekerja dengan kadar logam timbal yang terpapar pada rambut supir bis ditiga rute tersebut.

Tabel 2. Analisis Korelasi Masa Bekerja dengan Kadar Logam Timbal

\begin{tabular}{lccc}
\hline Sampel & Frekuensi (n) & Persentasi (\%) & Nilai r \\
\hline Dibawah ambang & 19 & $79,2 \%$ & 0,82 \\
batas & 5 & $20,8 \%$ & \\
Diatas ambang batas & 5 & \\
\hline
\end{tabular}

\section{PEMBAHASAN}

Berdasarkan hasil penelitian pada tabel 1 menunjukkan seluruh sampel teridentifikasi adanya logam timbal dirambut supir bus pada ketiga rute. Pada tabel 1 diperoleh kadar terendah ditemukan pada sampel TS7 di rambut supir bis rute Tangerang-Surabaya yaitu 0,17 mg $\mathrm{Pb} / 100$ g. Sedangkan untuk kadar terbesar ditemukan pada sampel TP1 sebesar 2,28 mg $\mathrm{Pb} / 100 \mathrm{~g} \mathrm{~Pb}$ pada rambut supir bis rute Tangerang-Padang. Selain itu masa bekerja supir bis juga mempengaruhi kadar logam timbal yang terpapar pada rambut supir bus tersebut. Hal ini terlihat pada sampel TS7 yang memiliki kadar timbal terendah mempunyai 
masa kerja relatif singkat sebagai supir bis yaitu selama 3 tahun. Sedangkan pada sampel TP1 dengan kadar logam timbal terbesar mempunyai masa kerja relative lama yaitu 25 tahun.

Sampel yang diamati dalam penelitian ini yakni berupa rambut, rambut dijadikan sebagai pemilihan sampel karena rambut memiliki beberapa kelebihan diantaranya yaitu memiliki jangka waktu memori yang panjang karena setiap tiga inchi rambut dapat menjelaskan riwayat yang terjadi pada tubuh selama 6 bulan. ${ }^{11}$ Identifikasi kadar logam berat melalui rambut lebih akurat dibandingkan dengan darah dan urine. ${ }^{12}$ Salah satu specimen yang dapat digunakan untuk melihat paparan kadar logam pada tubuh manusia dapat digunakan yaitu specimen rambut. Hal ini dikarenakan pada rambut tedapat protein struktural yang tersusun dari asam amino sistein yang mengandung gugug sulfhidril (-SH) dan sulfida sistin (-S-S). Pada gugus fungsi tersebut dapat mengikat logam berat yang masuk ke dalam tubuh dengan membentuk suatu ikatan kimia. $^{11}$

Berdasarkan hasil yang didapatkan tersebut bahwa semakin lama masa bekerja supir bus maka kadar $\mathrm{Pb}$ dalam rambut supir bus tersebut juga akan meningkat. Hal tersebut dikarenakan $\mathrm{Pb}$ memiliki sifat bioakumulatif dan biomagnifikasi, semakin lama terpapar oleh $\mathrm{Pb}$ maka akan semakin tinggi kadar $\mathrm{Pb}$ di dalam tubuh. ${ }^{13}$ Pekerjaan responden sebagai supir memiliki resiko selalu kontak langsung dengan udara yang tercemar $\mathrm{Pb}$, hal itu dapat terjadi saat melakukan perjalanan, selain itu kebiasaan responden yakni beristirahat, tidur, dan melakukan aktifitas lainnya seperti menunggu jam kerja atau selesai jam bekerja di terminal dalam keadaan kontak langsung dengan udara yang mungkin tercemar oleh $\mathrm{Pb}$.

Selain faktor lingkungan yang berhubungan dengan responden mempengaruhi kadar $\mathrm{Pb}$ dalam rambut, terdapat kebiasaan dari semua responden yang dapat menyebabkan terpaparnya $\mathrm{Pb}$ yakni merokok. Pada batang rokok mengandung $2,4 \mu \mathrm{g} \mathrm{Pb}$ dengan 5\% nya terdapat pada asap rokok. $^{14}$ Orang yang memiliki kebiasaan merokok berpotensi terpapar logam $\mathrm{Pb}$ lebih besar dibandingkan dengan orang yang tidak merokok. Hal ini disebabkan paparan logam $\mathrm{Pb}$ berasal dari batang rokok dan asap rokok tersebut. ${ }^{15}$

Absorpsi logam $\mathrm{Pb}$ kedalam tubuh ini dipercepat dengan kegiatan merokok tersebut.
Dengan merokok maka akan menggangu efektifitas sebagian mekanisme pertahanan respirasi, fungsi pergerakan silia menjadi menurun, dan merangsang produksi mukus ${ }^{15}$. Penurunan fungsi pergerakan silia tersebut mengakibatkan silia tidak dapat menyaring udara yang mengandung $\mathrm{Pb}$, sehingga $\mathrm{Pb}$ akan masuk kedalam paru-paru dan bercampur dengan darah. Pencampuran logam $\mathrm{Pb}$ yang toksik tersebut kemudian diedarkan keseluruh tubuh. ${ }^{16}$ Hal ini di dukung oleh peneilitian yang dilakukan oleh Dewi pada tahun 2015 dimana terdapat hubungan dengan kekuatan korelasi yang kuat antara kebiasaan merokok dengan kadar $\mathrm{Pb}$ dalam darah. Selain itu penelitian yang dilakukan oleh Wulandari pada tahun 2016 menyatakan bahwa terdapat hubungan yang signifikan antara kebiasaan merokok dengan kadar $\mathrm{Pb}$ dalam rambut. ${ }^{17}$

Emisi dari gas buangan kendaraan yang mengandung $\mathrm{Pb}$ dapat berupa partikel atau gas. Dengan komposisi sebanyak $10 \%$ dapat mencemari lokasi dalam radius kurang dari 100 meter dan sebanyak 5\% dapat mencemari sampai radius $20 \mathrm{~km}$ dan 35\% lainnya akan terbawa atmosfer dalam jarak yang cukup jauh, hal tersebut menunjukan bahwa emisi $\mathrm{Pb}$ tersebut dapat mencemarkan udara dimanapun kendaraan itu berada. ${ }^{13} \mathrm{~Pb}$ yang berada di udara rata- rata merupakan partikel yang memiliki ukuran diameter kurang dari $1 \mu \mathrm{m}{ }^{18}$ Timbal akan masuk kedalam tubuh salah satunya melalui saluran pernafasan. Oleh sebab itu pada rambut supir bis dapat teridentifikasi kadar logam timbal seiring dengan pekerjaan yang dijalaninya dan paparan dari lingkungan tempat bekerja. Hasil uji statistic analisis korelasi juga memberikan nilai $r=0,82$ yang menunjukkan adanya korelasi positif antara kedua variabel tersebut sebab memberikan hasil pengolahan statistic mendekati nilai 1 .

Nilai ambang batas yang aman kadar logam timbal dalam tubuh yaitu 0,007-1,17 $\mathrm{mg} / 100 \mathrm{~g} \mathrm{~Pb}{ }^{19}$ Rute masuk timbal dalam tubuh seseorang tidak hanya melalui inhalasi tetapi juga bisa melalui ingesti melalui air minum yang dikonsumsi hal ini dapat terlihat dari dosis potensial dan tingkat risiko kadar timbal yang masuk ke dalam tubuh seseorang. ${ }^{20}$ Walaupun demikian risiko pekerjaan yang dilakukan perlu mendapat perhatian khusus agar kadar logam timbal dalam tubuh tidak membahayakan kesehatan tubuh. 


\section{KESIMPULAN DAN SARAN}

Seluruh sampel rambut supir bus pada ketiga rute terminal bus Tanggerang PadangSurabaya - Yogyakarta yang dianalisis menunjukkan positif terpapar logam timbal dengan kadar yang bervariasi dari masingmasing rambut yang diperiksa. Namun kadar timbal yang ditemukan masih berada dibwah nilai ambang batas, meskipun demikian keberadaan timbal dalam spesimen rambut supir bus terdeteksi dalam jumlah yang masih aman,

\section{UCAPAN TERIMA KASIH}

Kami ucapkan terima kasih kepada laboratorium kesehatan DKI Jakarta yang telah

\section{DAFTAR PUSTAKA}

1. Dewi P, Sabilu Y, dan Pratiwi D. 2015. Faktor - faktor yang berhubungan dengan kadar plumbum $(\mathrm{Pb})$ dalam darah pada polisi lalu lintas di kota Kendari tahun 2015.

2. Ismiyati, Marlita D, Saidah D. 2014. Pencemaran Udara Akibat Emisi Gas Buang Kendaraan Bermotor. Jurnal Manajemen Transportasi \& Logistik. 1(3): 243.

3. Wulandari D, Abdullah S, dan Yulianto.2016. Hubungan lama merokok, lama bertugas dan arus lalu lintas kendaraan dengan kadr timbal $(\mathrm{Pb})$ dalam rambut polisi lalu linntas di kabupaten Magelang tahun 2016. POLTEKKES Semarang : $279-288$

4. Raharjo P, Raharjo M, Setiani O. 2018. Analisis Risiko Kesehatan dan Kadar Timbal Dalam Darah: (Studi Pada Masyarakat yang Mengkonsumsi Tiram Bakau (Crassostrea gigas) di Sungai Tapak Kecamatan Tugu Kota Semarang. Jurnal Kesehatan Lingkungan Indonesia. 17(1): 10.

5. Megalina Y. 2015. Pengaruh Pencemaran Udara Di Daerah Terminal Amplas Bagi Kehidupan Masyarakat. Jurnal Pengabdian Kepada Masyarakat. 21(79): 94

6. Gusnita D. 2012. Pencemaran Logam berat timbal $(\mathrm{Pb})$ diudara dan upaya penghapusan bensin bertimbal. Jurnal Berita Dirgantara. 13(3): 96. akan tetapi jika tidak segera diatasi dalam jangka waktu yang lama akan terakumulasi.

Penelitian lebih lanjut dapat dilakukan dengan paparan logam berat lainnya yang dimungkinkan akibat emisi buangan gas kendaraan disekitar terminal bis.Kepada pihak pemilik armada agar memperhatikan kesehatan supir bus dan melakukan pemeriksaan kesehatan terhadap supir-supir tersebut secara berkala.

membantu proses analisa identifikasi kadar logam timbal pada sampel.

7. Mukhtar R, dkk. 2013. Kandungan Logam Berat Dalam Udara Ambien Pada Beberapa Kota di Indonesia. Ecolab. 7(2): 56.

8. Ruslinda Y, Gunawan H, dan Goembira F. 2016. Pengaruh jumlah kendaraan berbahan bakar bensin terhadap konsentrasi timbal $(\mathrm{Pb})$ di udara ambien jalan raya kota Padang. Seminar Nasional Sains dan Teknologi Lingkungan II. E-ISSN 2541 - 3880 : 162 167.

9. Abidin, Z., Sunardi. 2009. Kualitas Udara Kota Yogyakarta Ditinjau dari Kadar Partikulat Timah Hitam (Pb). Indo, J., Chem. 9(3): 429.

10.Luo, R., Su, X., Xu, W. et al. Determination of arsenic and lead in single hair strands by laser ablation inductively coupled plasma mass spectrometry. Sci Rep 7, 3426 (2017). https://doi.org/10.1038/s41598-017-03660-6

11.Wiratma S,Sitorus S. 2018. Studi bioakumulasi ion logam $\mathrm{Pb}$ dalan rambut dan darah operator stasiun pengisian bahan bakar umum jalan Sentosa Samarinda. Jurnal Atomik. 03 (1) : 1- 8.

12.Putri A, Rosyada A, dan Sunarsih E. 2018. Analisis kadar timbal $(\mathrm{Pb})$ dalam rambut dan hipertensi pada pekerja PT. Bukit Asam Urut Dermaga Kertapati. Jurnal Ilmu Kesehatan Masyarakat. 9 (1) : 21 - 27. 
13.Adhani Rosihan dan Husalni. 2017. Logam Berat Sekitar Manusia. Banjarbaru

14.Firdaus N. 2015. Hubungan karakteristik responden dan kadar timbal $(\mathrm{Pb})$ dalam darah dengan kelelelahan kerja pada operator SPBU. Skripsi. Program Pendidikan (S1) Universitas Jember. Jember.

15.Wulandari D, Abdullah S, dan Yulianto.2016. Hubungan lama merokok, lama bertugas dan arus lalu lintas kendaraan dengan kadar timbal $(\mathrm{Pb})$ dalam rambut polisi lalu lintas di kabupaten Magelang tahun 2016. Poltekkes Semarang : $279-288$

16.Ronayan B. 2015. Hubungan karakteristik individu terhadap kdar timbal dalam darah dan dampaknya pada kadar hemoglobin pekerja percetakan di kawasan Megamall
Ciputat tahun 2015. Skripsi. Program Sarjana Kesehatan Masyarakat. Jakarta.

17.Dewi P, Sabilu Y, dan Pratiwi D. 2015. Faktor - faktor yang berhubungan dengan kadar plumbum $(\mathrm{Pb})$ dalam darah pada polisi lalu lintas di kota Kendari tahun 2015

18.Purnomo A. 2015. Hubungan timbal $(\mathrm{Pb}) \mathrm{di}$ udara dan yang ada di dalam darah terhadap kejadian anemia pegawai UPTD Dinas Perhubungan. Jurnal Vokasi Kesehatan. 1(2) : 45-53

19.Palar H. 2005. Pencemaran dan Toksikologi Logam Berat. Cetakan 4. Jakarta.

20.Maksuk M. 2019. Risk Quotient of Lead Concentration in Dug Wells Water at Community Arround Sukawinatan Dumping Site in Palembang City. In: Seminar Nasional Hari Air Sedunia. 2:10-17. 